MaPan : Jurnal Matematika dan Pembelajaran

p-ISSN: 2354-6883 ; e-ISSN: 2581-172X

Volume 6, No 1, June 2018 (104-118)

DOI: https://doi.org/10.24252/mapan.2018v6n1a10

\title{
PERANGKAT PEMBELAJARAN MATEMATIKA TERINTEGRASI KARAKTER-KEISLAMAN MELALUI PENDEKATAN KONTEKSTUAL DI PROPINSI RIAU
}

\author{
Suci Yuniati \\ Universitas Islam Negeri Suska Riau \\ Jl. Hr. Soebrantas No.155 Panam Pekanbaru Riau \\ E-mail: suciyuniati_mlg@yahoo.co.id
}

Submitted: 25-01-2018, Revised: 17-03-2018, Accepted: 01-05-2018

\begin{abstract}
Abstrak:
Penelitian ini bertujuan untuk menghasilkan alat pembelajaran matematika yang mengintegrasikan karakter-Islam melalui pendekatan kontekstual pada mata pelajaran matematika jenjag Madrasah Tsanawiyah (MTs). Jenis penelitian ini adalah penelitian pengembangan, dengan prosedur pengembangan, yaitu tahap pengumpulan data (observasi pendahuluan), membuat desain produk, evaluasi perangkat pembelajaran melalui tahap tinjauan ahli dan uji coba lapangan yang terbatas, serta analisis dan revisi sehingga menjadi produk akhir yang layak untuk digunakan sebagai alat pembelajaran. Hasil yang diperoleh dari penggunaan alat pembelajaran termasuk dalam kategori baik berdasarkan validasi skor untuk RPP, buku guru dan LKS dikategorikan sebagai sangat baik dan hasil belajar siswa dikategorikan sebagai baik, kemampuan guru untuk mengelola pembelajaran dan kegiatan siswa menunjukkan kriteria yang baik dan sangat baik, dan terjadi peningkatan hasil belajar siswa, walaupun tidak mencapai $85 \%$ siswa yang tuntas dalam suatu kelas.
\end{abstract}

Kata Kunci: Perangkat Pembelajaran, Karakter Islam, Kontekstual, Matematika

\section{MATHEMATICAL LEARNING TOOLS THAT INTEGRATES THE CHARACTER-ISLAMIC THROUGH A CONTEXTUAL APPROACH IN RIAU PROVINCE}

\begin{abstract}
:
This study aims to produce a mathematical learning tool that integrates the character-Islamic through a contextual approach on mathematics subjects for Madrasah Tsanawiyah (MTs) that is tested and feasible to be used in the learning process. Based on the result of the research, Learning tool through contextual approach integrated with Islamic character has been developed in accordance with the development procedure covering the stages data collection (preliminary observation), making product design, evaluation of learning device through
\end{abstract}


expert review stage and limited trials and field trials, as well as analysis and revision so as to be a viable end product to be used as a learning tool, the use of learning tools included in good category based on validation score for RPP, teacher book and LKS categorized as "excellent" And the students 'learning outcomes are categorized as "good", teachers' ability to manage learning and student activities show good and excellent criteria, and Improved student learning outcomes, although not $85 \%$ of completed students in a class.

Keywords: Learning Tools, Character Islamic, Contextual, and Mathematics

How to Cite: Yuniati, S. (2018). Perangkat Pembelajaran Matematika Terintegrasi Karakter-Keislaman Melalui Pendekatan Kontekstual di Propinsi Riau. MaPan : Jurnal Matematika dan Pembelajaran, 6 (1), 104-119.

asyarakat Indonesia dikenal sebagai masyarakat yang memiliki
karakter positif yaitu ramah-tamah, lemah lembut, dan sopan
santun. Namun dengan perubahan zaman dan teknologi yang semakin canggih karakter positif tersebut perlahan-lahan mulai ditinggalkan. Masyarakat yang terbiasa ramah tamah, santun berperilaku, melaksanakan musyawarah mufakat dalam menyelesaikan masalah, cenderung berubah menjadi karakter negatif seperti kekerasan dan kerusuhan, pergaulan bebas, korupsi yang merambah pada semua sektor kehidupan masyarakat, tindakan anarkis, penuturan bahasa yang buruk, tidak santun, penggunaan narkoba, suka melangkar aturan, pornografi yang terjadi dikalangan remaja, dan lain sebagainya (Supiana \& Sugiharto, 2017). Apabila suatu bangsa sudah tidak memiliki karakter yang tangguh, maka perlu segera dicari cara mengembalikannya. Dalam mengembalikan karakter positif diperlukan usaha yang menyeluruh dari semua pihak yaitu keluarga, masyarakat, dan sekolah (Sulistyowati, 2012).

Pembentukan karakter siswa sesungguhnya sudah tertuang dalam fungsi dan tujuan pendidikan nasional yaitu pendidikan nasional berfungsi mengembangkan dan membentuk watak serta peradaban bangsa yang bermartabat dalam rangka mencerdaskan kehidupan bangsa, bertujuan untuk berkembangnya potensi siswa agar menjadi manusia yang beriman dan bertakwa kepada Tuhan Yang Maha Esa, berakhlak mulia, sehat, berilmu, cakap, kreatif, mandiri, dan menjadi warga negara yang demokratis serta bertanggung jawab. Namun, dengan berbagai permasalahan yang terjadi di dunia pendidikan, fungsi dan tujuan pendidikan nasional itu seolah-seolah kurang maksimal dilaksanakan. Kurang maksimalnya penerapan tujuan dan 
fungsi pendidikan nasional dapat dilihat dari kondisi pendidikan di sekolah saat ini yang cenderung mengembangkan aspek kognitif siswa. Dalam hal ini, aspek selain kognitif seperti afektif kurang mendapat perhatian. Kenyataannya, guru hanya mengejar bagaimana hasil belajar siswa meningkat mulai dari hasil ulangan harian sampai hasil Ujian Nasional (UN). Kebanyakan guru dan kepala sekolah berprinsip, apabila sekolah yang dipimpinnya banyak siswa yang tidak lulus Ujian Nasional (UN), akan menjadi suatu musibah dan permasalahan yang sangat memalukan. Maka dari itu, pihak sekolah melakukan berbagai cara agar siswanya bisa lulus 100\%. Dengan demikian, pihak sekolah hanya mementingkan kemampuan siswa dari aspek kognitif saja tanpa memperhatikan aspek yang lain yaitu afektif. Hal ini juga disebabkan oleh sistem pendidikan yang lebih berorientasi pada mengejar target kurikulum, bahkan terkadang guru menunjukan sikap yang negatif terhadap pembentukan karakter siswa. Sebagai contoh, di suatu media diberitakan bahwa seorang wakil kepala sekolah melakukan pelecehan seksual kepada siswinya dan guru melakukan pemukulan kepada siswanya sehingga siswa tersebut tidak berani datang ke sekolah. Selain itu, teknologi yang semakin berkembang juga memberikan efek yang negatif jika kurang dikontrol. Sebagai contoh, kebanyakan siswa sibuk dengan dunianya sendiri (media sosial) tanpa memperhatikan lingkungan sekitar. Hal tersebut juga dapat dijumpai di lingkungan sekitar.

Melihat fenomena yang terjadi, maka perlu adanya implementasi pendidikan karakter di sekolah (Kamaruddin, Rahman, \& Djadir, 2014). Implementasi pendidikan karakter di sekolah dikembangkan melalui pengalaman belajar dan proses pembelajaran yang bermuara pada pembentukan karakter dalam diri siswa (Salafudin, 2015). Pendidikan karakter dalam kegiatan belajar mengajar di kelas, dilaksanakan menggunakan pendekatan terintegrasi dalam semua mata pelajaran (Sulistyowati, 2012). Pendidikan karakter diberikan secara terpadu melalui pengenalan nilai-nilai, fasilitas kesadaran akan pentingnya nilai-nilai, dan penginternalisasian nilainilai ke dalam tingkah laku siswa sehari-hari, baik di dalam maupun di luar kelas. Pada dasarnya kegiatan pembelajaran matematika, selain menjadikan siswa menguasai kompetensi (materi) yang ditargetkan, juga dirancang untuk menjadikan siswa mengenal, menyadari/peduli, dan menginternalisasi nilainilai karakter. Nilai-nilai karakter yang dapat dikembangkan adalah religius, berfikir kritis dan logis, rasa ingin tahu, toleransi, bertanggung jawab, mandiri, kreatif, jujur, menghargai karya dan prestasi orang lain, dan disiplin. Menurut 
(Sulistyowati, 2012) kegiatan pembelajaran matematika dalam kerangka pengembangan karakter siswa dapat menggunakan berbagai pendekatan, diantaranya pendekatan kontekstual sebagai konsep belajar mengajar yang membantu guru dan siswa mengaitkan antara materi yang diajarkan dengan situasi dunia nyata (Nurhadi, 2004), sehingga siswa mampu mengaitkan antara pengetahuan yang dimilikinya dengan penerapannya dalam kehidupan siswa. Dengan begitu, siswa memiliki kemampuan yang komprehensif tidak hanya pada tataran kognitif tetapi pada tataran afektif serta psikomotor. Hal tersebut juga didukung oleh penelitian yang dilaksanakan oleh (Johar, 2012) yang mengambil judul pengembangan bahan ajar pembelajaran matematika berbasis karakter melalui pendekatan realistik yang diterbitkan oleh Balitbang Kemendiknas tahun 2012. Dalam penelitian tersebut pengembangan bahan ajar pada jenjang Sekolah Dasar (SD) dan nilai karakter hanya dibatasi pada nilai kepercayaan diri, kreativitas, dan kemandirian. Maka dari itu, dalam penelitian ini mengembangkan nilai-nilai karakter yang lebih luas lagi yaitu religius, berfikir kritis dan logis, rasa ingin tahu, toleransi, bertanggung jawab, mandiri, kreatif, jujur, menghargai karya dan prestasi orang lain, dan disiplin. Dalam pengembangan penelitian ini dintergrasikan pada pembelajaran maka ada beberapa nilai karakter yang dituangkan dalam perangkat pembelajaran dan ada yang dipadukan dengan kegiatan pembelajaran di kelas dan luar kelas.

Tujuan penelitian ini adalah untuk menghasilkan perangkat pembelajaran matematika yang terintegrasi karakter-keislaman melalui pendekatan kontekstual pada mata pelajaran matematika jenjang Madrasah Tsanawiyah (MTs) yang teruji dan layak digunakan dalam proses pembelajaran.

\section{METODE PENELITIAN}

Penelitian ini merupakan penelitian pengembangan (Research $\mathcal{E}$ Developmental). (Borg \& Gall, 1989) mengemukakan bahwa pendekatan penelitian dan pengembangan, yaitu penelitian yang berorientasikan untuk mengembangkan, dan memvalidasi produk-produk yang digunakan dalam penelitian. Sedangkan menurut (Syaodih, 2015) penelitian dan pengembangan adalah suatu proses atau langkah-langkah untuk mengembangkan suatu produk baru atau menyempurnakan produk yang telah ada, yang dapat dipertanggungjawabkan. 
Model pengembangan yang digunakan dalam penelitian ini diadopsi dari model rancangan pengembangan dari Borg dan Gall dengan merancang dan memodifikasi model pengembangan tersebut ke dalam 5 tahap yaitu:

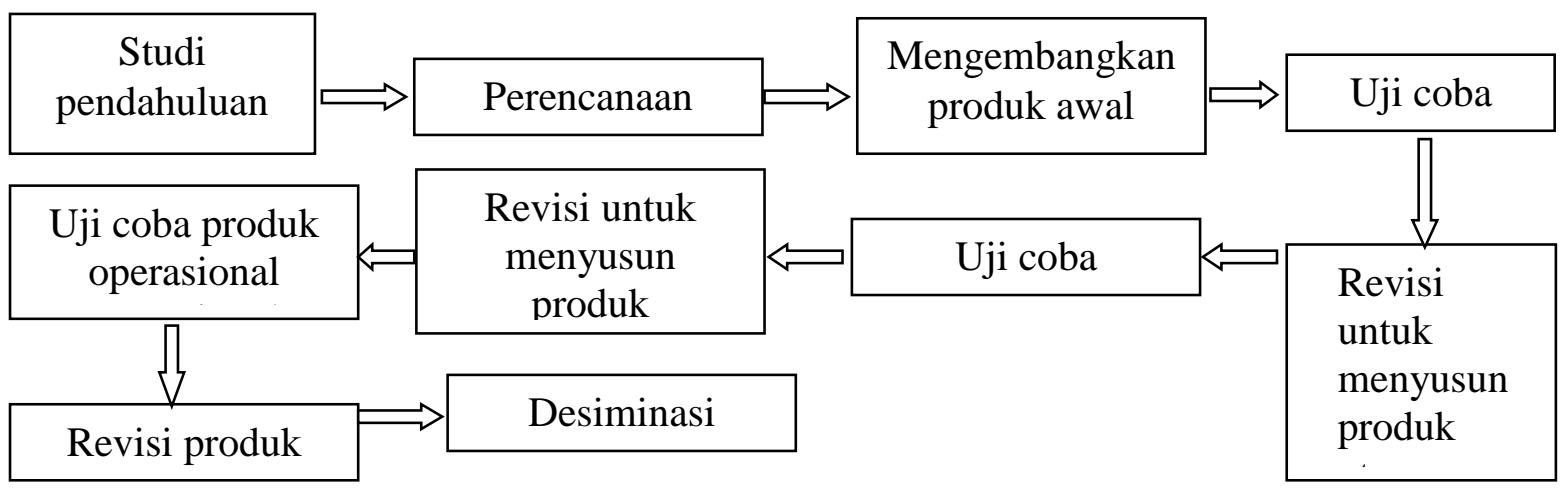

Gambar 1. Model Pengembangan Borg dan Gall

\section{a. Studi Pendahuluan}

Pada tahap ini berbagai informasi dikumpulkan terhadap kebutuhan yang akan berhubungan dengan mengembangkan produk berupa perangkat pembelajaran yang akan dihasilkan sesuai dengan KTSP yang sedang digunakan di sekolah. Pada tahap ini juga dilakukan observasi/pengamatan kelas mengenai proses pembelajaran yang sedang berlangsung pada kelas yang menjadi tempat penelitian.

\section{b. Desain Produk}

Setelah melakukan studi pendahuluan, selanjutnya menentukan tujuan pengembangan produk, memilih cakupan materi, sasaran dari produk, perumusan alat pengukuran keberhasilan dan beberapa hal lainnya yang terkait dengan persiapan pengembangan produk. Selanjutnya melakukan desain produk, adapun produk yang didesain dalam hal ini adalah perangkat pembelajaran melalui pendekatan kontekstual yang terintegrasi karakterkeislaman.

\section{c. Validasi}

Perangkat pembalajaran yang telah dirancang selanjutnya akan divalidasi oleh beberapa ahli sehingga dapat diketahui apakah perangkat pembelajaran tersebut layak dipakai seiring pemberlakuan kurikulum KTSP. Kegiatan penilaian ini dilakukan oleh tim penilai (evaluator). 


\section{d. Uji Coba dan Revisi Produk}

Hasil yang diperoleh dari kegiatan penilaian perangkat pembelajaran digunakan sebagai acuan untuk melakukan revisi I terhadap perangkat pembelajaran yang telah dibuat sebelumnya. Hasil revisi I selanjutnya digunakan untuk uji coba terbatas, setelah uji coba terbatas selanjutnya dilakukan revisi II terhadap perangkat pembelajaran sebelumnya. Hasil revisi II digunakan untuk uji coba lapangan dan dilakukan revisi III lagi jika diperlukan.

\section{e. Produk Akhir}

Berdasarkan hasil dari revisi-revisi perangkat pembelajaran tersebut terutama pada revisi III, selanjutnya disusun perangkat pembelajaran yang sistematis dan dapat digunakan sebagai panduan pembelajaran matematika.

Secara umum diagram proses pengembangan perangkat pembelajaran tersebut adalah sebagai berikut:

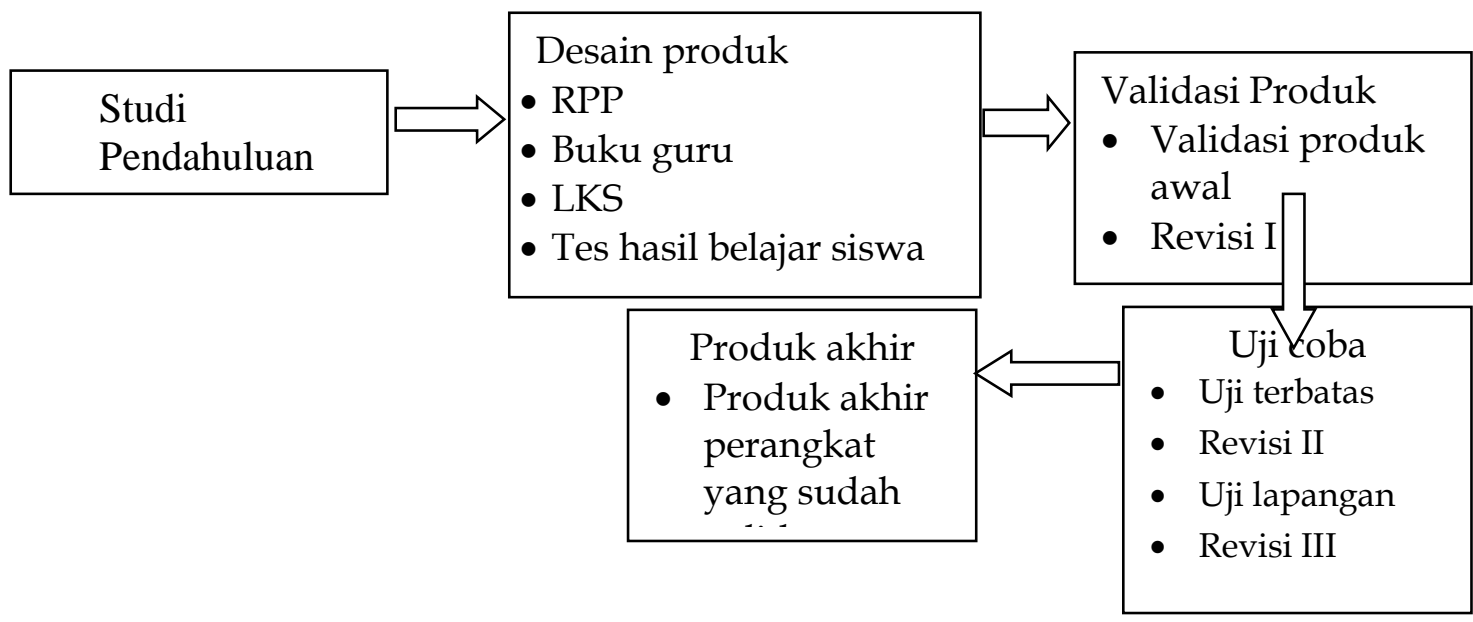

Gambar 2. Diagram Pengembangan Perangkat Pembelajaran

\section{Uji Coba Produk}

Desain uji coba pada penelitian ini terdiri dari 3 tahapan yaitu: validasi ahli, uji coba terbatas, dan uji coba lapangan. Subjek uji coba dalam penelitian ini adalah siswa kelas VII semester 1 MTs Al Munawwarah Pekanbaru berjumlah 30 siswa, MTs Al Muslimun Sei Kijang Pelalawan berjumlah 19 
siswa, dan MTs Negeri Lipat Kain Kampar berjumlah 32 siswa pada tahun ajaran 2015/2016.

Jenis data dalam penelitian ini berupa data kualitatif dan data kuantitatif. Data kualitatif diperoleh dari tanggapan ahli materi tentang kualitas produk dari aspek pembelajaran, materi (isi), dan tanggapan siswa tentang daya tarik perangkat pembelajaran. Data kuantitatif diperoleh dari skor tanggapan validator terhadap perangkat pembelajaran, skor pengelolahan pembelajaran oleh guru, angket siswa, dan skor tes hasil belajar siswa.

Instrumen pada penelitian ini terdiri dari: (a) lembar validasi perangkat pembelajaran, (b) lembar observasi pengelolahan pembelajaran, (c) lembar observasi aktivitas siswa, (d) angket respon siswa, dan (e) tes hasil belajar siswa.

Analisis data dalam penelitian ini bertujuan untuk menjawab pertanyaan penelitian yaitu mengembangkan dan menghasilkan perangkat pembelajaran matematika yang terintegrasi karakter-keislaman melalui pendekatan kontekstual yang baik dan efektif untuk mata pelajaran matematika di Madrasah Tsanawiyah (MTs). Data yang berupa komentar, saran revisi dan hasil obsevasi selama proses uji coba dianalisis secara deskriptif kualitatif dan disimpulkan sebagai masukan untuk merevisi produk yang dikembangkan, sedangkan data yang berupa skor tanggapan ahli, skor pengelolahan pembelajaran, skor aktivitas siswa, skor angket respon siswa, dan tes hasil belajar siswa.

\section{Analisis Data Hasil Validasi Perangkat Pembelajaran}

Data berupa skor tanggapan validator yang diperoleh dalam bentuk kategori yang terdiri dari lima pilihan tanggapan tentang kualitas produk perangkat pembelajaran yang dikembangkan, yaitu sangat baik (5), baik (4), cukup (3), kurang (2), dan sangat kurang (1). Data tersebut diubah menjadi data interval. Skor yang diperoleh kemudian dikonversikan dalam bentuk data kualitatif skala lima sebagai berikut:

Tabel 1. Skor Acuan Validasi Perangkat Pembelajaran

\begin{tabular}{ccc}
\hline Nilai & Interval skor & Kriteria \\
\hline A & $X i+1,8 S B i<X$ & Sangat baik \\
B & $X i+0,6 S B i<X \leq X i+1,8 S b i$ & Baik \\
C & $X i-0,6 S B i<X \leq X i+0,6 S b i$ & Cukup
\end{tabular}




\begin{tabular}{ccc}
\hline $\mathrm{D}$ & $X i-1,8 S B i<X \leq X i-0,6 S b i$ & Kurang \\
$\mathrm{E}$ & $X \leq X i-1,8 S b i$ & Sangat kurang \\
\hline
\end{tabular}

Keterangan:

$\mathrm{Xi} \quad$ : Rerata skor ideal $=$ setengah $($ skor maksimum + skor minimum $)$

SBi : Simpangan baku ideal $=$ seperenam (skor maksimun - skor minimum)

X : Skor aktual

Selain masukan dan saran validator perangkat pembelajaran dikatakan efektif untuk digunakan uji coba jika rata-rata skor perangkat pembelajaran mempunyai kategori baik. Dengan demikian jika hasil analisis data tidak memenuhi kategori baik maka akan dijadikan pertimbangan untuk merevisi perangkat pembelajaran sebelum diujicobakan.

\section{Analisis Data Hasil Pengelolahan Pembelajaran}

Data tentang kemampuan guru dalam pengelolaan pembelajaran matematika melalui pendekatan kontekstual yang terintegrasi keislamankarakter yang diamati, dianalisis dengan menggunakananalisis persentase. Analisis menggunakan skala 1 sampai 5. Jumlah skor perolehan masingmasing indikator disebut jumlah skor, sedangkan jumlah skor ideal masingmasing indikator disebut skor maksimal. Presentase skor perolehan yang disingkat SP diperoleh dengan cara mengalikan hasil bagi jumlah skor dan skor maksimal dengan $100 \%$ atau dengan rumus:

Persentase Skor Perolehan $(S P)=\frac{\text { Jumlah skor }}{\text { Skor maksimal }} \times 100 \%$

Kemampuan guru dalam mengelolah pembelajaran dikatakan efektif jika rata-rata skor tiap RPP berada pada kategori baik. Dengan demikian maka hasil analisis data yang tidak memenuhi kategori baik pada penelitian ini akan dijadikan pertimbangan untuk merevisi perangkat pembelajaran yang telah diujicobakan.

\section{Analisis Data Aktivitas Siswa}

Data tentang aktivitas siswa dianalisis dengan menggunakan analisis persentase. Analisis menggunakan skala 0 sampai 2. Data aktivitas siswa berisi perilaku siswa selama proses pembelajaran yang berisi tentang: (1) mendengarkan/memperhatikan penjelasan guru, (2) membaca LKS, (3) menanggapi pertanyaan teman, (4) bertanya jika belum mengerti, dan (5) membuat dan mencatat kesimpulan. Skor tiap butir dari jawaban siswa akan 
dianalisis, kemudian diinterpretasikan dalam bentuk persentase. Jumlah skor perolehan masing-masing indikator disebut jumlah skor, sedangkan jumlah skor ideal masing-masing indikator disebut skor maksimal. Presentase skor perolehan yang disingkat SP diperoleh dengan cara mengalikan hasil bagi jumlah skor dan skor maksimal dengan $100 \%$ atau dengan rumus:

$$
\text { Persentase Skor Perolehan }(S P)=\frac{\text { Jumlah skor }}{\text { Skor maksimal }} \times 100 \%
$$

Aktivitas siswa dikatakan efektif jika rata-rata skor tiap RPP berada pada kategori baik. Dengan demikian maka hasil analisis data yang tidak memenuhi kategori baik pada penelitian ini akan dijadikan pertimbangan untuk merevisi perangkat pembelajaran yang telah diujicobakan.

\section{Analisis Data Respon Siswa}

Data angket respon siswa juga dianalisis untuk mengetahui respon siswa terhadap penggunaan pembelajaran melalui pendekatan kontekstual terintegrasi karakter-keislaman dalam proses pembelajaran. Analisis menggunakan skala Likert yaitu 1 sampai 5. Skor tiap butir dari jawaban siswa akan dianalisis, kemudian diinterpretasikan dalam bentuk persentase. Interpretasi skor respon siswa mengikuti pedoman dari (Riduwan, 2015) pada tabel 5 .

Tabel 2. Interpretasi Kriteria Skor Respon Siswa

\begin{tabular}{cc}
\hline Kreteria Rentang Persentase & Kategori \\
\hline $0 \%-20 \%$ & Sangat Kurang \\
$21 \%-40 \%$ & Kurang \\
$41 \%-60 \%$ & Cukup \\
$61 \%-80 \%$ & Baik \\
$81 \%-100 \%$ & Sangat Baik \\
\hline
\end{tabular}

\section{Analisis Tes Hasil Belajar Siswa}

Analisis tes hasil belajar siswa yang dilakukan dalam penelitian ini adalah dengan melihat validitas tes, reliabilitas tes, dan skor ketuntasan siswa. a). Validitas Tes

Suatu instrumen dikatakan valid apabila instrumen tersebut dapat digunakan untuk mengukur apa yang seharusnnya diukur (Sugiyono, 2009). Untuk mengetahui validitas tes pada penelitian ini, maka dihitung validitas 
tiap-tiap butir tes dengan menggunakan rumus korelasi produk moment berikut:

$$
r_{x y}=\frac{N \sum X Y-\sum X \sum Y}{\sqrt{\left(N \sum X^{2}-\left(\sum X\right)^{2}\right)\left(N \sum Y^{2-}\left(\sum Y\right)^{2}\right.}}
$$

Keterangan:

X : Skor item

Y : Skor total

$\mathrm{N} \quad$ : Banyak siswa yang mengikuti tes

$\mathrm{r}_{\mathrm{xy}} \quad$ : Koefisien korelasi skor item dan skor total

Untuk interpretasi terhadap besarnya koefisien korelasi, harga r-hitung dikonsultasikan dengan harga r-tabel dengan taraf kesalahan 5\%. Jika harga rhitung yang diperoleh lebih besar r-tabel maka butir soal tersebut dikatakan valid, namun jika harga r-hitung yang diperoleh lebih kecil dari r-tabel maka butir soal tersebut direvisi atau dibuang.

b). Reliabilitas Tes

Uji reliabilitas instrument bertujuan untuk mengetahui taraf-taraf kepercayaan kuesioner/angket dan tes tersebut sebagai alat pengumpul data. Reliabilitas mengacu pada konsistensi atau keterpercayaan hasil ukur. Suatu alat evaluasi dikatakan reliabel jika hasil pengukurannya relatif tetap jika digunakan untuk subjek yang sama. Untuk menentukan reliabilitas tes, peneliti pengacu pada pendapat (Sugiyono, 2009) yang mengatakan bahwa pengujian reliabilitas dengan teknik alfa Cronbach dilakukan untuk jenis data interval atau essay. Rumus koefisien reliabilitas Alfa Cronbach adalah:

$$
r_{i}=\frac{k}{(k-1)}\left\{1-\frac{\sum s i^{2}}{s t^{2}}\right\}
$$

Keterangan:

$\mathrm{k} \quad$ : Jumlah siswa yang mengikuti tes

$\sum s i^{2}:$ Mean kuadrat kesalahan

$s t^{2} \quad$ : Varians total

Untuk menginterpretasikan koefisien reliabilitas (r) digunakan panduan kriteria sebagai berikut:

$$
\mathrm{r}_{11}<0,20 \quad \text { derajat reliabilitas sangat rendah }
$$




$$
\begin{array}{ll}
0,20 \leq \mathrm{r}_{11}<0,40 & \text { derajat reliabilitas rendah } \\
0,40 \leq \mathrm{r}_{11}<0,60 & \text { derajat reliabilitas cukup } \\
0,60 \leq \mathrm{r}_{11}<0,80 & \text { derajat reliabilitas tinggi } \\
0,80 \leq \mathrm{r}_{11} \leq 1 & \text { derajat reliabilitas sangat tinggi }
\end{array}
$$

Berdasarkan interpretasi tersebut, dalam penelitian ini butir tes dikatakan baik jika koefisien reliabilitasnya minimal dalam kategori cukup. Dengan demikian butir-butir tes yang memiliki koefisien realibilitas di bawah kategori cukup akan direvisi.

\section{c). Skor Ketuntasan Siswa}

Analisis tes hasil belajar siswa yang dilakukan dalam penelitian ini dengan melihat skor ketuntasan siswa. Hasil belajar siswa ditentukan berdasarkan penilaian acuan patokan. Skor yang diperoleh siswa melalui tes hasil belajar akan digunakan untuk menentukan ketuntasan individual dan ketuntasan klasikal siswa. Ketuntasan individual atau per siswa ditentukan dengan rumus:

$$
p=\frac{s_{i}}{s_{m}} \times 100 \%
$$

Keterangan:

$\mathrm{P}=$ Persen ketuntasan belajar per siswa

$\mathrm{S}_{\mathrm{i}}=$ Jumlah skor yang dicapai siswa terhadap seluruh butir soal

$\mathrm{S}_{\mathrm{m}}=$ Jumlah skor total seluruh butir soal

Siswa dikatakan tuntas belajarnya jika proporsi jawaban benar, atau persen ketuntasan belajarnya 65\%. Suatu kelas dikatakan tuntas belajarnya jika di kelas tersebut terdapat $85 \%$ siswa telah mencapai ketuntasan individual.

\section{HASIL PENELITIAN DAN PEMBAHASAN}

Penelitian ini dilakukan pada siswa kelas VII MTs Al Munawwarah Pekanbaru, MTs Al Muslimun Sei Kijang Pelalawan, dan MTs Negeri Lipat Kain. Jadwal penelitian yang dilakukan di sekolah tersebut adalah sebagai berikut: (1) MTs Al Munawwarah Pekanbaru padatanggal 23 September 2015 21 Oktober 2015 , (2) MTs Al Muslimun Sei Kijang Pelalawan pada tanggal 14 September 2015 - 29 September 2015, dan (3) MTs Negeri Lipat Kain pada tanggal 19 Oktober 2015 - 4 November 2015. Dalam uji coba lapangan peneliti dibantu 3 observer yang berperan sebagai pengamat aktivitas siswa dan aktivitas guru pada saat mengajar di kelas dan terdapat 5 validator yang bertugas memvalidasi perangkat pembelajaran. 
Tes awal (pre-test) dilaksanakan setelah observasi awal, pre-test bertujuan untuk mengetahui kemampuan awal siswa, sedangkan tes akhir (post-test) diberikan pada akhir pelaksanaan pembelajaran pada uji coba lapangan. Tujuan post-test adalah untuk mengetahui kemampuan siswa setelah pelaksanaan pembelajaran dengan menggunakan pendekatan kontekstual yang terintegrasi karakter-keislaman. Bentuk soal adalah essay yang berjumlah 4 soal. Kegiatan uji coba merupakan salah satu kegiatan inti dari penelitian ini. Kegiatan uji coba dalam penelitian ini terdiri dari uji coba terbatas dan uji coba lapangan. Observasi dilaksanakan bersamaan pada kegiatan uji coba lapangan. Kegiatan uji coba dan observasi dilakukan untuk memperoleh informasi yang akan digunakan untuk merevisi produk yang dikembangkan. Pemberian angket respon siswa dilakukan diakhir pelaksanaan penelitian yaitu setelah uji coba lapangan dan post-test diberikan. Angket ini bertujuan untuk mengetahui respon siswa terhadap perangkat pembelajaran dan strategi yang telah digunakan.

\section{Analisis Data}

Analisis data pada penelitian ini terdiri dari:

a. Lembar Validasi Perangkat Pembelajaran

Berdasarkan hasil validasi terhadap perangkat pembelajaran diperoleh skor rata-rata yang dapat di lihat pada tabel berikut ini:

Tabel 3. Skor Perangkat Pembelajaran

\begin{tabular}{ccc}
\hline Perangkat Pembelajaran & Skor Aktual & Kriteria \\
\hline Rencana Pelaksanaan Pembelajaran (RPP) & 4,07 & Sangat Baik \\
Buku Guru & 4,05 & Sangat Baik \\
Lembar Kerja Siswa (LKS) & 4,05 & Sangat Baik \\
Tes Hasil Belajar & 3,91 & Baik \\
\hline
\end{tabular}

Berdasarkan tabel 1, diketahui bahwa skor rata-rata RPP, buku guru, dan LKS berada pada kriteria sangat baik, sedangkan tes hasil belajar berada pada kriteria baik yang berarti bahwa perangkat pembelajaran yang merupakan produk awal sudah dapat digunakan pada uji coba setelah melakukan beberapa revisi berdasarkan saran dan masukan validator. 
b. Lembar Observasi Pengelolahan Pembelajaran

Dari hasil pengamatan pengelolahan pembelajaran oleh guru di sekolah MTs Al Muslimun persentase RPP 1 sampai RPP 4 dalam kategori sangat baik sehingga tidak dilakukan revisi perangkat pembelajaran.Data pengelolahan pembelajaran matematika untuk MTs Al Munawwarah persentase RPP 1 sampai RPP 4 dalam kategori sangat baik sehingga tidak dilakukan revisi perangkat pembelajaran.Data pengelolahan pembelajaran matematika untuk MTs Negeri Lipat Kain persentase RPP 1 sampai RPP 4 dalam kategori sangat baik sehingga tidak dilakukan revisi perangkat pembelajaran.

\section{c. Lembar Observasi Aktivitas Siswa}

Hasil observasi aktivitas siswa menggunakan skala 0 sampai 2. Data aktivitas siswa untuk MTs Al Muslimun persentase RPP 1 dan RPP 2 pada ketegori baik, sedangkan RPP 3 dan RPP 4 dalam kategori sangat baik sehingga tidak dilakukan revisi perangkat pembelajaran. Data aktivitas siswa untuk MTs Al Munawwarah persentase RPP 1 sampai RPP 4 pada ketegori sangat baik, sehingga tidak dilakukan revisi perangkat pembelajaran.Data aktivitas siswa untuk MTs Negeri Lipat Kain persentase RPP 1 dan RPP 2 pada ketegori baik, sedangkan RPP 3 dan RPP 4 dalam kategori "sangat baik" sehingga tidak dilakukan revisi perangkat pembelajaran.

\section{d. Angket Respon Siswa}

Data dari 81 siswa yang terdiri dari 19 siswa MTs Al Muslimun Sei Kijang Pelalawan, 30 siswa MTs Al Munawwarah Pekanbaru, dan 32 siswa MTs Negeri Lipat Kain Kampar yang mengisi angket respon siswa hanya 77 siswa yaitu 17 siswa MTs Al Muslimun Sei Kijang Pelalawan, 28 siswa MTs Al Munawwarah Pekanbaru, dan 32 siswa MTs Negeri Lipat Kain Kampar. Angket respon siswa diberikan diakhir pembelajaran melalui pendekatan kontekstual terintegrasi karakter-keislaman. Hasil angket respon siswa terhadap LKS terletak pada kriteria sangat baik. Hasil angket respon siswa terhadap proses pembelajaran terletak pada kriteria sangat baik. Hasil angket respon siswa terhadap penyelesaian tes terletak pada kriteria baik

\section{e. Tes Hasil Belajar}

1. Validitas dan Realibilitas Tes

Hasil perhitungan validitas hasil belajar siswa dari 8 soal yang didesain, ada 4 soal dalam kategori valid. Sedangkan dari hasil analisis reabilitas tes, 
diperoleh skor reabilitas dengan kategori cukup, ini berarti bahwa perangkat tes memiliki keajegan/konsistensi yang cukup untuk digunakan sebagai alat penilaian hasil belajar siswa.

2. Skor Ketuntasan Siswa

Dari hasil tes yang diperoleh, persentase hasil belajar siswa mengalami peningkatan, namun tidak mencapai $85 \%$ siswa yang tuntas belajarnya dalam suatu kelas. Oleh karena itupembelajaran yang menerapkan perangkat pembelajaran melalui pendekatan kontektual yang terintegrasi karakter-keislaman pada pokok bahasan bilangan pecahan dapat meningkatkan kualitas hasil belajar siswa.

\section{Keterbatasan Penelitian}

Dalam penelitian ini terdapat beberapa keterbatasan yaitu:

a. Kurang matangnya persiapan dalam menyusun perangkat pembelajaran dikarenakan mengejar materi yang diajarkan.

b. Saat melaksanakan penelitian di propinsi Riau terjadi kabut asap dan sekolah diliburkan sehingga proses pembelajaran menjadi terganggu.

c. Akibat kabut asap salah satu lokasi penelitian mengajarkan materi bilangan pecahan dalam satu hari (dipadatkan).

\section{SIMPULAN}

Berdasarkan pembahasan diperoleh kesimpulan bahwa: (1) perangkat pembelajaran melalui pendekatan kontekstual terintegrasi karakter-keislaman telah dikembangkan sesuai dengan prosedur pengembangan yang meliputi tahap pengumpulan data (observasi awal), membuat desain produk, evaluasi terhadap perangkat pembelajaran melalui tahap review ahli, uji coba terbatas dan uji coba lapangan, serta analisis dan revisi sehingga menjadi produk akhir yang layak digunakan sebagai perangkat pembelajaran, (2) penggunaan perangkat pembelajaran termasuk dalam kategori bagus berdasarkan hasil skor validasi RPP, buku guru dan LKS berkategori sangat baik dan tes hasil belajar siswa berkategori baik, (3) kemampuan guru mengelola pembelajaran dan aktivitas siswa masing-masing menunjukan kategori baik dan sangat baik, dan (4) terjadi peningkatan tes hasil belajar siswa, walaupun tidak mencapai $85 \%$ siswa yang tuntas dalam suatu kelas.

\section{DAFTAR PUSTAKA}

Borg, W \& Gall, M. (1989). Education research. New York: Longman.

Johar. (2012). Pengembangan bahan ajar pembelajaran matematika berbasis karakter 
melalui pendekatan realistik. Jakarta: Balitbang Kemendiknas.

Kamaruddin, R., Rahman, A., \& Djadir. (2014). Pengembangan perangkat pembelajaran matematika materi geometri berbasis teori belajar Van Hiele untuk mengembangkan karakter siswa kelas VII1 SMP 2 Bulupoddo. MaPan : Jurnal Matematika dan Pembelajaran, 2 (1), 63-74.

Nurhadi. (2004). Kurikulum 2004. Jakarta: PT Gramedia Widiasarana Indonesia.

Riduwan. (2015). Belajar mudah penelitian untuk guru, karyawan dan peneliti pemula. Bandung: Alfabeta.

Salafudin. (2015). Pembelajaran matematika yang bermuatan nilai Islam. Jurnal Penelitian, 12 (2), 223-243.

Sugiyono. (2009). Metode Penelitian kuantitatif kualitatif dan RED. Bandung: Alfabeta.

Supiana \& Sugiharto, R. (2017). Pembentukan nilai-nilai karakter Islami siswa melalui metode pembiasan (Studi Kasus di Madrasah Tsanawiyah Terpadu Ar-roudloh Cileunyi Bandung Jawa Barat). EDUCAN: Jurnal Pendidikan Islam, 1 (1), 89-109.

Sulistyowati, E. (2012). Implementasi kurikulum pendidikan karakter. Yogjakarta: PT Citraaji Parama.

Syaodih, N. (2015). Metode penelitian pendidikan. PT Remaja Rosdakarya Offset. 